\title{
Información y desinformación. La II guerra mundial a través del NO-DO
}

\author{
Josefina MARTÍNEZ
}

\section{INTRODUCCIÓN}

El primer lunes de 1943, unos acordes compuestos por el maestro Parada y una campanas al vuelo seguidas de un águila imperial sorprendían los oídos y los ojos de aquellos españoles que, guarecidos del frío y para olvidar el hambre, se encontraban en las 4.000 salas de cine que entonces habia en el territorio nacional.

Chicos y grandes se desconcertaron ante una narración en perfecto castellano sin ese deje gangoso de los noticiarios de la FOX, la dureza del acento en los reportajes de la UFA o el tono más melódico del castellano hablado por cronistas del LUCE italiano. También las imágenes eran más cercanas. El NO-DO se estrenaba en su n 1 con el ambiente navideño de la plaza Mayor de Madrid, unas jovencitas sonrientes que cerraban paquetes para los voluntarios de la División Azul, un partido de fútbol entre la selección aérea italiana y nuestro Atlético de Aviación, una demostración deportiva en Berlín, los nuevos peinados de París, la cosecha algodonera en Ucrania, una misión comercial española en Argentina, la llegada de Muñoz Grandes desde el frente en olor de multitud, Franco entregando despachos a los nuevos oficiales del Estado Mayor, el día de acción de gracias en Londres, un desfile de tropas ante Hiro-Hito y, para terminar, el frente de guerra en el Cáucaso y en el sector central soviético.

Sin saberlo, los espectadores asistían al nacimiento del noticiario español que en este número mostraba una sintesis de todos los temas que, al menos durante los tres años restantes, coparian los primeros 15 minutos de las ansiadas sesiones de cine. A partir de este momento y durante 32 años, hasta septiembre de 1975, NO-DO tendría el monopolio de la información cinematográfica de actualidad que se proyectase en nuestro país. 
Por una orden de la Vicesecretaria de Educación Popular del 17 de diciembre de 1942, (“BOE» del 22 de diciembre), firmada por Gabriel Arias Salgado, se crea "la entidad de carácter oficial Noticiarios y Documentales Cinematográficos NO-DO (...) que editará y explotará, con carácter exclusivo, el Noticiario Cinematográfico Español (...) siendo este organismo el único que en el futuro podrá llevar a cabo el intercambio de noticias cinematográficas con el extranjero".

La orden continuaba con 5 escuetos artículos en los cuales se añadia que - a partir de ese momento- en ningún punto de España y sus colonias se podia proyectar otro noticiario que no fuera el NO-DO, ningún operador podía obtener reportajes y ningún laboratorio manipularlos sin la autorización de NO-DO y se establecía la obligatoriedad de su exhibición en todos los locales cinematográficos del territorio nacional.

Con las consignas de instruir, informar y entretener a todos los españoles nacia el noticiario español NO-DO. El Régimen, tras una guerra civil e inmerso en la guerra europea - de forma neutral o no beligerante, según los momentos-, necesitaba de un órgano propio de información audiovisual y, por fin, ya lo tenía.

\section{¿DE DÓNDE PROCEDE LA INFORMACIÓN?}

A pesar de esta orden y de que fueran nacionalizados todos los elementos de los distintos noticiarios que elaboraban reportajes de España para el exterior UFA, LUCE, FOX MOVIETONE, etc., no resultó tan sencillo poner en funcionamiento el proyecto. En primer lugar, en España no se fabricaba pelicula virgen, por lo que se dependía de las importaciones y, con la guerra, resultaba difícil conseguir las partidas; en segundo lugar, no contaba NO-DO con laboratorios propios que pudieran positivar y montar los negativos. Ambas carencias fueron satisfechas. De Alemania venía la película virgen para rodar y, después, en los laboratorios madrileños Riera y Madrid Films, se empezó a positivar el negativo, que iría

\footnotetext{
Asimismo, en el Deutsche Wochenschau aparecen varias noticias relativas a España: la reunión en Hendaya de Hitler y Franco ( $A X$ 120); la visita de Serrano Súñer a Berchstengaden para entrevistarse con Ribbentrop, Ciano, Keitel y Hitler (AX 247) en noviembre de 1940 o la reunión de Mussolini y Franco en Bordighera el 12 de febrero de 1941. Existe un documental de la Acción Nacional Suiza contra el Comunismo titulado "La peste roja» dedicándose cerca de 20 minutos a la guerra civil española, donde se expone la evolución del conflicto y remarcando que España es uno de los antecedentes del conflicto mundial (AX 235). Todas ellas se conservan en el archivo de NO-DO y aqui se indica su número de signatura.
} 
después acompañado de las noticias venidas del extranjero. Aquí se les ponía el texto, la voz en off, se limaba ligeramente la imagen para acoplar el sonido y se acomodaban las locuciones de las arengas triunfalistas tanto de los noticieros alemanes como, posteriormente, los reportajes estadounidenses o británicos con el fin de que resultasen más asépticos ${ }^{2}$.

Hasta mediados de 1951, año en que NO-DO tiene ya sus propias instalaciones, el noticiario se realiza de este modo. No es de extrañar que la información sobre los aliados sea menor. Antes del número 23a -junio de 1943 - con una noticia sobre Leslie Howard (muere al ser alcanzado su avión por los alemanes ${ }^{3}$ ) y el $25 \mathrm{~b}$ en que aparecen las nuevas lanchas salvavidas, no se da ni una sola noticia de Estados Unidos o los países aliados en lo tocante al conflicto bélico.

Un 40 por ciento de los números que exhibe el NO-DO desde enero de 1943 hasta enero de 1946 se ocupan de la Segunda Guerra Mundial. En los 181 números que abarca este período, tanto en la versión $A$ como $B$ del noticiario, el conflicto bélico será el tema dominante. De las 52 horas que suma este material, cerca de 20 horas se dedican a él. En la mayoría de los números de NO-DO hasta la victoria sobre el Japón (142a), de los 8 reportajes que ofrecía el noticiario, al menos 3 se referían al conflicto bélico. Las insulsos reportajes nacionales o internacionales de bailes y bodas típicas, acontecimientos deportivos o taurinos, modas, inventos o actos oficiales no tienen el menor peso especifico frente a los reportajes de guerra.

Lógicamente, la información va evolucionando en el mismo sentido que la propia guerra, aunque cuesta separarse de la tendencia germanófila ${ }^{4}$. La dirección de NO-DO, que hasta el desembarco en Sicilia (40a) ha mantenido la tónica de dar noticias de, sobre y venidas de Alemania, se vuelve más «imparcial». Se empiezan a montar más imágenes sobre los aliados, sin perder "la objetividad", presentando -en principio- tanto la victoria del Reich como la aliada en cualquiera de los reportajes. Ambos

\footnotetext{
2 Todo este proceso se aprecia en algunos reportajes que se han conservado con el sonido original al perderse o reutilizarse la banda sonora española.

3 Los aliados conocian las claves de radio alemanas desde principios de 1943. Gracias a eso descifraron un mensaje en el que se decia que el avión que trasladaba a Leslie Howard a Londres, después de dar una serie de conferencias en favor de los aliados, iba a ser derribado. Se vieron en la disyuntiva de salvar al actor o no mostrar sus conocimientos, optando por lo segundo.

4 Se ha negado en varias ocasiones la tendencia germanófila del NO-DO - declaraciones de Alberto Reig, subdirector del noticiario en sus origenes y posteriormente director- y $V$. SANCHEZ Biosca y R.R. Tranche: NO-DO: El tiempo y la memoria. Madrid. Filmoteca Española, 1993, p. 35, pero, tras nuestro visionado y análisis, no to consideramos así.
} 
contrincantes cumplen siempre con los objetivos marcados. A partir de enero de 1944, y de forma gradual, un lenguaje más aséptico, sobre todo en los frentes europeos, y una construcción en cada número del noticiario más equilibrada se impondrá en la manera de elaborar el noticiario que ya ofrece una noticia procedente de Alemania y una inglesa o norteamericana. Esta estructura se mantendrá hasta el final de la contienda, no habrá vencedores ni vencidos en Europa, la ecuanimidad perdura durante toda la guerra, ¿pero, qué guerra?

\section{LA GUERRA DE LOS ESPAÑOLES}

Queda claro, a través de múltiples informaciones del noticiario, que la guerra civil española es el inicio de la cruzada contra el comunismo que supone la II Guerra Mundial. Reportajes sobre el discurso de Franco en la apertura de las Cortes de 1943 (13); varios recordatorios titulados “'Españoles, acordaos!” $(14,22 a)$, donde se mezclan imágenes de la guerra civil, de Paracuellos y el descubrimiento de la fosa de Katyn en Polonia; la imposición de la Medalla de la Ciudad de Madrid a Franco (15); el discurso de Jordana en las fiestas colombinas de 1943 (18) o la reconstrucción de las fábricas de Sabadell destruidas por "las hordas marxistas (...) legado siniestro de la revolución roja" (29a) son motivos suficientes para explicar - a través de la imagen y la palabra- que España paró «la revolución roja» y que Franco "liberó a España de esta carroña" (30b). Ahora es el turno de Alemania de defender a Europa, desde las posiciones conquistadas en el Este, del "peligro rojo".

Pero España, a pesar de haber defendido su territorio del comunismo y haberlo liberado de este peligro, no se desentiende del drama europeo. El gobierno español, que aparece en varios reportajes del NO-DO, reiterará en todo momento su "estricta neutralidad" durante todo el conflicto. Informa a los espectadores de su actitud de «no ceder ante ninguna presión para mantener nuestra posición» (59a), a la vez que "España se mantiene en orden y paz bajo el signo del Caudillo" (105b).

Aún así, España participará en la guerra de forma activa al enviar a Rusia la División Azul o de manera más tangencial con misiones humanitarias. En el momento de nacer el NO-DO, los voluntarios están casi por volver. En el primer número hay dos reportajes referidos a ellos, tal y como se ha señalado más arriba: preparación de regalos de navidad para enviar a los divisionarios y regreso de Muñoz Grandes del frente. Dos números después, podemos ver como Muñoz Grandes es condecorado por Hitler con las hojas de roble de Caballero de la Cruz de Hierro por su heroica 
labor. Varios números posteriores los ocupan las visitas de Esteban infantes a las tropas en el frente $(19,23 b, 28 a)$, asi como una entrevista de Lindemann y Esteban Infantes (31a) y la visita de la madrina de la División, Celia Jiménez a los voluntarios (5). A los soldados apenas se les ve en acción (sólo en el $n^{\circ} 7$, luchando en primera línea «sin importarles el fragor de la batalla ni la dureza del terreno"), sí se ve cómo se les condecora, forman, juegan con la nieve, oyen misa y regresan sanos y salvos a Irún $(19,23 b, 28 a)$, lo que seguramente tranquilizaría a las familias de los voluntarios. Desgraciadamente muchas de estas imágenes eran de dos años antes: formaban parte de un noticiario de la UFA realizado en 1941 (AX 248) y se montaron para el NO-DO. Fue un claro ejemplo de manipulación informativa.

De los voluntarios que no regresaron en este tren de mediados de 1943 , no se volverá a saber nada hasta el regreso de los 286 prisioneros que después de un cautiverio de entre 11 y 13 años llegarian a Barcelona en el Semíramis el 2 de abril de $1954{ }^{5}$. Posteriormente, en octubre de 1956 llegarán a Valencia otros 532 repatriados de Rusia (718a).

La otra vertiente que se presenta en el NO-DO de la participación española en la guerra mundial, vendrá marcada por su neutralidad. Se trata de los intercambios de prisioneros que se suceden en el puerto de Barcelona. En presencia de la Cruz Roja Española y de los embajadores inglés y alemán tiene lugar un primer intercambio de 2.144 prisioneros y heridos de ambos países. La noticia se verá la segunda semana de noviembre de 1943. Las damas de la Cruz Roja entregan flores y cigarrillos, mientras el cuerpo diplomático saluda afectuosamente a los compatriotas para los que la guerra ha terminado y regresan a sus hogares $(45 a, 45 b)$.

En mayo de 1944 se volverá a efectuar la misma operación en Barcelona bajo la mirada amable y vigilante de la Cruz Roja. Esta vez serán 2.000 heridos alemanes, norteamericanos y británicos los que vuelvan a su patria $(74 b)$.

El último apunte que presenta el NO-DO de las relaciones de España con los paises beligerantes será a través de las diversas noticias del cuerpo diplomático establecido en Madrid. Los reportajes serán escasos:

\footnotetext{
5 Los divisionarios fueron objeto de un documental «La División Azul Española», realizado por Victor de la Serna y Alberto Reig en 1942 que narra -empezando por la guerra civil-el enganche de voluntarios, su llegada a Berlin, acciones bélicas, la vida de los soldados y el relevo de la división ya en Madrid (AX 235). El tono triunfal, la victoria sobre el comunismo y la heroicidad de los voluntarios será el hilo conductor de este documental.
} 
- Las relaciones, más bien de tipo cultural, que se mantienen con Alemania: visita del agregado cultural a la Academia José Antonio (10) y apertura del centro hispano-germano en Madrid (12).

- Representantes norteamericano y británico pasando la frontera de Irún para entrevistarse con el coronel Ortega a mediados de septiembre de 1944 (90a).

- Cambio del embajador italiano por la muerte del Conde Lequio en enero de 1943. Las imágenes mostrarán el funeral y entierro (5). El nuevo embajador presentará sus credenciales a finales de abril (19).

- Relevo en la delegación alemana. En febrero de 1943 se enviará un nuevo ministro plenipotenciario (5), que fallece en Madrid al mes siguiente y sus restos deberán ser trasladados a Alemania. Las honras fúnebres vestirán de banderas nazis toda la Gran Via (14). En abril, el nuevo embajador será recibido por Franco y el conde de Jordana. La Gran Vía, una vez más, tendrá el dudoso honor de engalanarse con svásticas por doquier (20a).

- Muerte en mayo de 1944 del agregado aéreo británico. Un desfile militar acompañará sus restos fúnebres por las calles de Madrid (75a). Poco después llegará su sucesor (76b).

- Llegada al aeropuerto de Barajas, a finales de marzo de 1945, del nuevo embajador americano, momento que toman las cámaras del noticiario (117a). A la semana siguiente presenta sus credenciales ante el Jefe del Estado (118a).

\section{LA GUERRA DE LOS ALEMANES}

A través del NO-DO podemos apreciar la imagen que esta institución tenía de la guerra desde el punto de vista de los alemanes. En principio, el enemigo se encuentra en el frente ruso, es la guerra contra "las hordas asesinas del carnicero Stalin» (22a). Parece que el único enemigo que existe es el comunismo. Los títulos de los reportajes "La lucha contra el comunismo" y "Cruzada contra el comunismo", se repiten en la mayoria de los números hasta el desembarco en Sicilia (40a). A partir de entonces el epígrafe será «En el frente del Este» ó «En el frente germano soviético» y el tema recurrente de la ofensiva contra los bolcheviques - palabra que aparece en la mayoría de los reportajes - pasa a segundo término a partir de los números de enero de 1944.

En ningún momento la Wehrmacht pierde en el frente del Este. Siempre "después de un duro combate en el que las fuerzas alemanas han llevado 
la iniciativa, el puesto ha sido conquistado, las órdenes se han cumplido" (30b). Esta frase sintetiza el discurso general de los reportajes de este frente. Desde el número 1 en que aparecen esquiadores en el Cáucaso realizando "el maravilloso deporte de la muerte", ya sea los stukas que "destruyen los objetivos bolcheviques" $(3,5,10,13,15,19 \ldots)$ o atacan ciudades como Leningrado -denominado constantemente San Petersburgo-, Kuban, Charkov, ya sean los submarinos en el mar del Norte o en el mar Negro, la artillería pesada y ligera, la infantería o los paracaidistas, los alemanes siempre vencen.

Deformada nuestra idea de la guerra por el plano y contraplano de las películas de ficción, aquí nos falta el enemigo. Sólo hay dos reportajes en los que aparecen algunos prisioneros rusos que "serán recluidos en campos de concentración" $(31 b, 32 b)$, primera vez que aparece este término sin el matiz adquirido posteriormente tras el exterminio judio.

Las imágenes de guerra propiamente dichas, en el primer año de NO-DO, son planos generales muy abiertos donde a varios kilómetros caen las bombas o se aprecian los disparos contra los aviones. Parece desmesurada la toma de algunos objetivos: impresionantes baterías se utilizan contra pequeñas cabañas de paja. Nunca se ven muertos, ni rusos ni, por supuesto, alemanes. Sí son más "cinematográficas" las imágenes de aviones alcanzados que caen a tierra (34b, 51b, 52b, $54 a \ldots)$. A partir de Sicilia y Normandía los planos son más cortos y se pueden ver los combates en las calles. El horror es más cercano. Las imágenes bélicas en todos los frentes se vuelven más cruentas y afectan más al espectador.

Siempre serán los “adversarios» los que destruyan en sus bombardeos objetivos no previstos. Serán los bolcheviques los que destrocen iglesias que han de reconstruir los alemanes a su paso por diversas poblaciones (8), pero nunca se identifica en los textos a "los adversarios" - los aliados- que en diversas ciudades europeas, por ejemplo Bruselas, destruyen la ciudad y alcanzan a civiles (46a).

Muchos de los reportajes que se ofrecen, muestran la labor de reconstrucción alemana en los territorios conquistados. Gracias a la invasión alemana, Moravia, Ucrania, Francia «hacia 80 años que no se conseguian cosechas como la de este año" y todas las zonas invadidas van a salir del subdesarrollo. Desde luego aumenta todo tipo de producción agrícola, ganadera y mecánica $(40 \mathrm{~b}, 43 \mathrm{~b}, 52 \mathrm{~b} . .$.$) . También se informa de cómo eran$ las escuelas de oficiales, el adiestramiento de todos los cuerpos de todos los ejércitos, las fábricas, la construcción y el funcionamiento de las armas, la reconstrucción de carreteras, ferrocarriles, telecomunicaciones, 
los beneficios del estado nazi, el cuidado por la infancia, la vida en la retaguardia, su arte, el amor a la familia...

"...La población que no quiere caer en manos bolcheviques y sigue a las tropas con alegría..." (43b). Esta frase -utilizada para describir el éxodo de la población civil- resumiria muchas de las noticias que ofrece el NO-DO de los grupos de jóvenes que se unen a la causa nazi: húngaros que marchan al frente del Este $(1,12)$, el juramento de las juventudes holandesas (12), condecoraciones con cruces de hierro a los soldados finlandeses (12), noruegos y franceses incorporándose a filas (20a), letones y lituanos subiendo a los trenes (20b) e incorporándose voluntariamente al trabajo (78a), cosacos voluntarios (24b), la legión de Flandes y las SS de Bruselas (25b), jóvenes españoles escapados de la URSS que llegan a Berlín (3), camisas negras (44b)... En ningún momento deja la población de participar en el conflicto apoyando la causa nazi. Europa no está invadida, sino salvada del comunismo.

En muy pocos reportajes se dan cifras de bajas en ninguno de los frentes. De destrucción de maquinaria bélica sólo se apunta, en octubre de 1943 que, en dos semanas, en el sector central del frente del Este han sido destruídos 4.300 tanques soviéticos (33a). En este momento será la primera vez que se indique que "los aviones bolcheviques entorpecen el avance alemán", aunque los alemanes infligen "pérdidas constantes a los soviéticos en su maquinaria de guerra" (33b). Ya ha tenido lugar el desembarco en Sicilia, visto en el mismo noticiario desde el lado aliado y alemán. Las noticias que se dan son de avances tanto de unos como de otros. Mes y medio después se vuelve a ver los cúltimos combates en Sicilia" ya únicamente desde el lado británico, donde planeadores "descargan pertrechos para las operaciones defensivas" y "la artilleria alemana se pone en acción para proteger la retirada" (40a). En el cielo siciliano "se desarrollan escenas dramáticas". Las escuadrillas alemanas "refuerzan la retirada, mientras las tropas del Reich luchan" (40b). Será la única vez que el texto y las imágenes den por terminada una batalla en la que los alemanes evacuen una zona. Nunca quedará claro que pasó en África ni en el frente soviético.

\section{a) El frente de África}

La guerra en el frente de África apenas tiene reflejo en el noticiario. En enero de 1943 la situación del norte de África no puede tener un discurso lineal como el que se desarrolla en el frente soviético. La situación no es clara para los alemanes. Ha tenido lugar la contraofensiva del Alamein y, 
al frente de Eisenhower, las tropas angloamericanas han desembarcado en Marruecos y Argelia. Tropas alemanas e italianas, en Túnez, avanzan hacia Taburba (3), lo que ya es recogido por el NO-DO. Pero el Eje es derrotado tras la pérdida de Tripolitania y se mantiene la resistencia en el sur de Gabes y Túnez occidental. Aún así, se presentan a finales de febrero reportajes que muestran el cuartel general germano-italiano en Túnez y una entrevista entre Rommel y Cavallero (7). Dos semanas después se podrán ver combates en el frente de Tánger, así como el desembarco de tropas y municiones (9) y operaciones de un destacamento de vanguardia alemán que es recibido por los habitantes de los poblados de la zona (11). En el siguiente número se ofrece un reportaje sobre contingentes italianos que regresan a Brindisi y Venecia y civiles repatriados, seguido de otra noticia en la que los carros blindados alemanes avanzan hacia el Atlas. Los aviones salen de Sicilia y Túnez y la artilleria opera en el sector norte hasta llegar a Gafsa (13), noticia que se da en la primera semana de abril de 1943. Será la última vez que el NO-DO informe sobre el frente de África. Es como si desapareciera la guerra del mapa. No se informará al mes siguiente de la capitulación del África Korps y la toma de 252.000 prisioneros italo-alemanes.

\section{b) El frente de Italia}

A partir de estos momentos, verano de 1943, el tono triunfal de la guerra, desciende. Se aprecia como en los textos la guerra ya comienza a ser algo dramático que no parece tener fin (34b). Es como si los propios redactores del noticiario empezaran a estar cansados de la cruenta situación que asola al planeta. El lenguaje que, hasta el desembarco en Sicilia habia sido, tanto en los reportajes nacionales como en los venidos de Alemania durante este primer período, duro, despiadado, demoledor, cargado de ira y rencor (lo mismo que los noticiarios originales americanos contra los japoneses, ya algo después) no se traducirá al sonido español en el mismo tono. Los textos hablan menos de la necesidad de la guerra, son menos las veces en que «las tropas alemanas son el más firme baluarte contra la invasión bolchevique" (38b). Desde las pantallas se aboga por la paz con frases que expresan deseos como "cuando acabe la guerra y llegue la paz».

Los sucesos de Italia no fueron un paseo militar. Lo demuestra el gran número de reportajes que se ocupan de la guerra en este territorio. A lo largo de todo el discurso de la redacción del noticiario no hay una toma de postura. Ciertamente, se narran los acontecimientos y se puede apreciar lo 
cruento de las batallas, pero da la sensación de que no se quiere reconocer el retroceso de los alemanes.

En agosto de 1943, una vez desembarcadas las tropas aliadas en Sicilia ( $34 a$ y $34 b$ ), no deja de haber ataques y contraataques de ambos bandos. En el NO-DO, hasta seis semanas después no se considera conquistada Sicilia por los aliados (40a), ya en octubre de 1943. Los alemanes han de replegarse al continente sin abandonar la lucha.

Los reportajes sobre Italia se ofrecerán con una cadencia más lenta, cada dos ó tres semanas, no como los del frente del Este que siguen ocupando casi todos los números. Las noticias llegarán tanto de los noticiarios alemanes como de los norteamericanos, a veces en el mismo número y seguidas.

Aunque los alemanes son saludados por los italianos en su repliegue y "en el sur de Italia las fuerzas del Reich se desprenden del adversario y sus avanzadas combaten en primera línea contra contingentes angloamericanos (...) donde el terreno se disputa palmo a palmo" (43b), al retroceder hacia el norte, en Trieste, vemos a los camisas negras que se incorporan a los ejércitos del Reich (44b). Sin embargo, los bombarderos de la RAF actúan sobre Nápoles bloqueando las comunicaciones (47a) y el $5^{\circ}$ ejército aliado establece una cabeza de puente sobre el Volturno que dará lugar a "una de las fases más importantes de la guerra en Italia» (48b). Rommel aparece en el siguiente reportaje inspeccionando las fortificaciones de la muralla blindada en el norte de Italia y se cestablecen nuevas posiciones para el tiro libre" (49a).

En las siguientes 10 semanas no hay información sobre la guerra en Italia, sólo en enero de 1944 habrá unas imágenes de Mussolini con su nuevo consejo de ministros (53a) y, a mediados de febrero, se incide en la ocupación por angloamericanos de posiciones alemanas - con su defensa antiaérea- en el sur de la península (58a).

Si el desembarco a principios de enero de 1944 en Anzio y la toma de Roma pudieron haber sido cuestión de horas, la indecisión del mando norteamericano provocó una carnicería y el retraso en la llegada de la paz. Dieron tiempo a los alemanes a reforzar sus defensas en Monte Cassino lo que hizo que, del 15 de febrero al 30 de mayo la guerra se manifestara de la forma más brutal. Hasta casi un mes después del desembarco no llegan a España imágenes de los acontecimientos de Anzio (63a) que se proyectan a la par que noticias sobre el cuartel alemán en Monte Cassino y escenas bélicas de defensas y ataques de ambos contendientes por campiñas y poblados. 
A mediados de marzo de 1944, Mussolini visita al nuevo embajador alemán y se omite cualquier otra información de Italia hasta dos semanas después en que las fuerzas aliadas del $5^{\circ}$ ejército y el $99^{\circ}$ aerotransportado norteamericanos y el $8^{\circ}$ británico, tras 26 dias de bombardeos, "disputan el terreno palmo a palmo en este sector" centroitaliano. A continuación podemos apreciar los avances tanto de la infantería como de la artillería nazi, sus reservas de municiones, baterías antiaéreas en Monte Cassino (65b, 66a). Quince días después parece que la guerra se ha detenido: sólo hay noticias de la Luftwaffe sobre los Apeninos, soldados que quitan nieve en los pasos de montaña o esquían en Noruega; los americanos practican el paracaidismo y los barcos pesqueros franceses salen a faenar protegidos por los alemanes. Pero, en realidad se avanza sobre Crimea, en el frente ruso se siguen devastando poblados y se han bombardeado ciudades alemanas y Londres.

Cuando se retoma la información, a principio de mayo de 1944, sobre Monte Cassino están cayendo " 2.500 toneladas de bombas en una milla cuadrada" según informan los norteamericanos. A su vez, los alemanes muestran como la ciudad ha quedado convertida en escombros: la abadia ha sido destruída (69b). Las fuerzas antiaéreas alemanas, la artillería pesada y ligera no ceja en la defensa y el ataque de todo el territorio (70a).

Para ambos contendientes la naturaleza dificulta las operaciones. EI deshielo convertirá los campos en barrizales intransitables (71b) y, para colmo, el Vesubio entra en erupción. Los aliados han de preocuparse no sólo de la guerra sino del fuego y la destrucción de los ríos de lava (75b).

Pero la guerra en Italia pasará a un segundo plano ante las noticias procedentes del desembarco de Normandía y el nuevo frente abierto en el Atlántico. Hasta mediados de septiembre de 1944 no vuelven a aparecer en las pantallas imágenes de Italia. Será para mostrar al rey de Inglaterra revistando a sus tropas en Nápoles así como a los polacos que participaron en Monte Cassino y Ancona (91b). Quince días después se verá la defensa alemana de Pisa y Rávena y, a continuación, los combates en Florencia del $8^{\circ}$ ejército hasta la entrada de los aliados en la ciudad (93b). Este reportaje prácticamente es coetáneo a los acontecimientos. A la semana siguiente se podrá ver la enorme cantidad de material transportado por el $7^{\circ}$ ejército en Nápoles (94b).

A partir de este momento y excepto alguna que otra información sobre la acción de las SS contra la resistencia en varios puntos de Italia (109a), una división alemana que dispara lanzacohetes contra unas ruinas defendidas por un tanque (111a), la vigilancia alemana en la frontera francoitaliana (113b), un viaje del Duce a Milán (119a) y, por último, el Papa 
recibiendo a los aliados $(124 a)^{6}$, en el NO-DO no aparecen más noticias de Italia.

Nunca se informó ni de la caída de Mussolini, ni de la constitución del nuevo gobierno dirigido por Pietro Badoglio, ni de la proclamación del armisticio y las represalias subsiguientes, ni de la huida del rey y la creación de la república de Saló o la declaración de guerra de Italia a Alemania. Tampoco se supo de la capitulación de las fuerzas alemanas en Italia, en abril de 1945, ni se vieron las imágenes que dieron la vuelta al mundo de Mussolini asesinado por los partisanos y colgado junto a Clara Petacci.

\section{c) El frente del Este}

Desde el noticiario número 1 al 99b existe en el NO-DO una sección dedicada exclusivamente a la guerra en Rusia. La situación que se presenta apenas varía a lo largo de los casi 100 números.

Al quedar las tropas alemanas embolsadas en dos zonas tras el cerco de Stalingrado y capitular el 31 de enero de 1943 las fuerzas del sur y el 2 de febrero las del norte con cerca de 90.000 alemanes prisioneros, las noticias que llegan son de los sectores de los frentes central y norte. En todo momento parece que los alemanes dominan a los rusos. Se ven imágenes de armamento destruído en el Cáucaso (18), la cliberación de la tenaza de hierro en San Petersburgo" donde se derrota a la artillería y se derriban aviones (19) además de luchar contra la nieve y el deshielo a lo largo de todo el período bélico.

La cabeza de puente del Kuban, su cañaveral, será otro de los centros de atención bélica. Bombardeos aéreos y terrestres (31a, 32b, 33b, 34b) muestran las posiciones alemanas. También en el mar Negro, donde se construyen refugios y los stukas bombardean sin cesar, dando la impresión de dominio alemán (32a, 52b). Otro centro de atención del informativo será Orel donde las comunicaciones y los puentes quedarán destruídos (38a, 38b).

Alemania intensifica su producción de armamento con destino al frente ruso $(28 a, 29 a)$. Los envites siempre van acompañados por lanzamientos que ocultan a las tropas y protegen los convoyes (29a). Los submarinos

También habia bendecido a los obreros de los cuerpos especiales alemanes en Roma (Organización Todt) y había condenado "las teorías subversivas del comunismo" (29a) en julio de 1943. 
atacan a los buques soviéticos (61b). En muchos reportajes los alemanes aparecen tranquilos, en las pausas del combate (52a), reparando el armamento (68a) o se muestra el aprovisionamiento del frente (65b). Aún a mediados de marzo de 1944 se dan noticias del «avance alemán" y la victoria en Crimea cuando, realmente, será evacuada al mes siguiente (69a). Quince días después informaciones de noticiarios americanos muestran el abandono de las columnas blindadas germanas (71a) ${ }^{7}$, aunque se siga dando informaciones sobre el envío de reservas a la zona de Leningrado, de convoyes al mar Negro, se derriban aviones bolcheviques -ahora imágenes llegadas de Alemania- (72b, 74b) y se libera las tropas situadas en Kurks, después de 25 dias de asedio (75b).

En septiembre de 1944 el NO-DO muestra la nueva línea defensiva soviética cerca de Vilna, vecina ya a la frontera polaca "para oponerse al avance bolchevique». La población civil se traslada con las tropas alemanas ya que "no quiere volver a sentir los horrores del comunismo" (89a). Por el sur la nueva frontera bélica se establece en la rivera del Dnieper (92b). Los soviéticos han recuperado hasta Kiev, pero los alemanes "siguen avanzando" (93a) y siguen llegando refuerzos.

A mediados de octubre de 1944, por primera vez se dirá en el texto que "los alemanes y húngaros resisten y los rusos avanzan» (99b). El discurso general mantiene la tónica del contraataque del Reich y rechazo de las ofensivas por la artillería (102b). En diciembre de 1944 todavía se construyen nuevas fortificaciones (104b) y los stukas destruyen más de 400 tanques bolcheviques (108b).

En estos momentos, en que está a punto de caer Budapest ya no se indican los frentes ni las zonas de guerra. Las imágenes del frente del Este son mucho más encarnizadas en las pantallas (105a, 105b, 106b), incluso se ve a la artillería americana que avanza por el Don (107a).

Los frentes italianos y después atlántico desviarán, en cierto modo, la atención sobre la zona rusa y, al retomar la información, desaparecen los enunciados de los reportajes del frente del Este. Se incluyen en otro bloque más general denominado "Reportajes de guerra" (100 a) en los que los alemanes "ponen todo su heroismo para resistir la ofensiva soviética" (116a). Se sigue remarcando que los alemanes luchan "contra la ofensiva soviética (...) y abren brechas en la base enemiga (...) a lo largo de los $1.000 \mathrm{~km}$. de frente" (118b). Pero ya la guerra para Alemania está

El texto tiene narración norteamericana. 
perdida, porque en estos momentos los aliados ya están estrechando la mano de los soviéticos en Torgau.

Las siguientes imágenes referidas a Alemania serán la liberación de prisioneros de los campos de concentración y el descubrimiento de los horrores de esta masacre (125a), el desarme de las tropas alemanas (126b), la entrega de los altos mandos (127a) y la firma de la rendición por parte de Von Friedeburg en el cuartel general de Montgomery (127b). Posteriormente los procesos de Nüremberg cerrarán la información.

\section{c) La guerra del Japón y del Pacifico}

Al resultar mucho más lejana de España la guerra del Pacífico, la información es más ajena que los acontecimientos de la guerra en Europa, y, por ello, es menor. En torno a 60 reportajes se ocupan de dar a conocer la situación, cantidad ínfima comparada con los cerca de 1.100 reportajes dedicados a todo el conflicto mundial durante los tres años y medio que abarca la información.

La guerra del Japón es, asimismo, parte de la lucha contra el comunismo. La invasión de la China roja en la zona de Yunann donde clos nipones aniquilan a los comunistas de la China de Chun Kin. Queda limpio El territorio de los últimos focos de inquietud" (15) es un ejemplo del discurso que se sigue durante todo el conflicto. Además, Japón se defiende «de la tenaza que le infligen los norteamericanos" invadiendo Borneo (1), Nueva Guinea —ocupación de Saramago y bombardeo de Puerto Darwin (23a)-, Birmania (32a)...

Se presenta a los japoneses como disciplinados gimnastas $(28 \mathrm{~b}, 33 \mathrm{~b}$, $60 a)$, que desfilan ante su emperador (1), visitan exposiciones en Viena (85a), y están hermanados con los alemanes (45b) - su embajador visita a Hitler (89b, 96b) - que tienen parte de su flota de submarinos en el Indico (55b, 63b), para ayudar a los nipones.

Por su parte los aliados son ayudados por los indígenas a defenderse en Birmania "de los beligerantes" (36b). Cuando ya ha tenido lugar la batalla del mar de los Corales y se ha detenido la expansión japonesa hacia el sur, a partir del verano de 1945, dará comienzo la gran ofensivá del Pacífico.

Excepto algunos reportajes del principio del NO-DO, la mayor parte de la información sobre esta zona del conflicto mundial llega desde Estados Unidos y, claro, se va viendo la victoria de los aliados. En diciembre de 1943 el NO-DO da la noticia de la "ofensiva más importante 
de las operaciones militares de los aliados" que está teniendo lugar en Birmania (51a, 60b, 72b),donde, todavía, en noviembre de 1944 "se han hecho fuertes las fuerzas japonesas" (95a), en enero de 1945 continúan los combates (104b). Las imágenes serán duras. Se ven muy cercanos los enfrentamientos, los lanzallamas, el avance de las tropas y la artillería ligera (58b).

A partir de estos momentos se ofrecen varios reportajes sobre la acción de los portaaviones en las islas Marshall $(60 a, 65 a)$ y combates en toda la zona del Pacífico (62b, 70a, 85b) para reconquistar las Aleutianas (64a), Nueva Guinea (56b, 57a), las islas del Almirantazgo -atacadas por sorpresa por Mac Arthur- (71a), Raboul (74b), las Marianas -la $5^{\text {a }}$ flota protege el asalto a Saipán, a 500 millas de Tokio- (88a), Guam "primer jalón hacia el Japón y Filipinas» (90a) -noticia dada en septiembre casi concluidas las operaciones-, el desembarco de marines y llegada de tropas aerotransportadas que avanzan hacia la capital totalmente devastada (95b, 97a). Los japoneses van siendo obligados a replegarse hacia sus territorios (72a) y, por fin, el general Mac Arthur regresa a Filipinas upara cumplir su palabra (...) y destruir 900 barcos japoneses» (102a, 108b).

Los B-29 comienzan sus incursiones sobre Tokio, la capital del imperio nipón, con 7 millones de habitantes. Desde las islas Saipan a $2.700 \mathrm{Km}$. de distancia salen miles de aviones para bombardear durante más de 2 horas (109b). Entretanto, en Birmania, los aliados intentan «impedir a los japoneses, con enormes esfuerzos, que lleguen a Mandalay" (110b).

Mac Arthur y las tropas del almirante Nimitz entablan grandes combates en Leyte para conquistar las Filipinas. Durante dos días la $3^{\mathrm{a}}$ y la $7^{\mathrm{a}}$ flota no cejan en la ofensiva (111a). La aviación no afloja en los bombardeos preparando la llegada del $6^{\circ}$ ejército, hasta conseguir la caída de Luzón (114b, 116a). Mac Arthur libera Manila y salva a los rehénes civiles que aún quedan con vida (124b). La 37 división acaba con la resistencia japonesa (134a).

Mientras tanto, la $14^{\mathrm{a}}$ división británica avanza hacia Mandalay construyendo en 26 horas un puente (111b). Tropas norteamericanas desembarcan en Birmania (114a). El paso ya es transitable. Se pueden enviar suministros desde la India a China (122b). La llegada de la 38 división, apoyada por las fuerzas aéreas, facilita la marcha de la infantería (127a). Se desfila triunfalmente una vez tomada Rangún (138a). Para entonces, Filipinas y Nueva Guinea ya han sido liberadas (121a).

40.000 soldados de la $5^{\mathrm{a}}$ división, 20.000 jeeps y 4.000 aviones se encuentran a $1.000 \mathrm{kms}$. de Tokio (123b). Comienza la ofensiva aérea, definida 
como una "proeza de valentía y organización». Mientras los americanos "perdieron 9 aeroplanos" han destruido " 571 aviones y 55 buques" japoneses (125b).Tokio y Okinawa son bombardeadas «el 90\% de los aviones japoneses caen al mar» (126a), "50.000 enemigos han muerto" (134a). Los buques británicos se unirán a los norteamericanos para concluir la guerra contra el Japón (137b). Por primera vez aparecerán en las pantallas los «kamikazes dispuestos a morir ante la derrota que les espera" (137b), aunque "la guerra extraña de los kamikazes causa muchas bajas, no aplazará la derrota del Japón" (141b). En el número siguiente se anuncia su capitulación (142a).

\section{LA GUERRA DE LOS ALIADOS}

Como ya se ha indicado, la información sobre los aliados tarda en aparecer en el NO-DO y es únicamente descriptiva, sin tomar posturas ideológicas. A mediados de 1944 solamente uno de cada 8 reportajes que componen cada número - y no de todos - se dedica a los aliados. En el apartado titulado «Reportajes de guerra» se va promediando la información de los frentes alemanes y de los diferentes conflictos abiertos en todo el mundo. Por lo general los reportajes proceden de Estados Unidos, aunque algunos sean de origen británico.

En un principio, muchos de los reportajes dedicados a los aliados no hacen referencia a la guerra en sí, sino a la evolución del armamento y la industria bélica que, por otra parte, también se ha mostrado respecto a Alemania. Baterías antitanques que "ayudaron a derrotar a los nazis en Salerno" (44a), autobuses gigantes para el transporte de 250 soldados (47a), aircraft que hacen recorridos de los aviones a los portaaviones (49b), barcazas que transportan jeeps (51b), portaaviones gigantes (59b), globos que protegen convoyes (70a), bombas de gran calibre (70b), aviones sin motor (73b), aviones B-25 que arrojan bombas con paracaidas (75b)... El transporte de tropas será otro tema a tener en cuenta. La cantidad de material y hombres que se moviliza es impresionante. En diciembre de 1943 se organizan 65 trenes con 1.300 vagones para la infanteria (47b).

Todo es válido para concienciar a la población del estado de guerra. El sistema de propaganda americano funciona tan bien como el alemán pero sus parámetros son diferentes. Si los nazis utilizan el esplendor de su bellos jóvenes desfilando ante el Fhürer, la grandiosidad del estado nazi, su arquitectura y escultura monumental, los americanos también utilizan sus 
bazas más espectaculares, las estrellas de cine: Clark Gable de servicio (50a), artistas de la pantalla se trasladan a Washington para vender bonos (52b), Robert Taylor se entrena como aviador (61b), Carole Lombard que muere en un accidente de aviación cuando se trasladaba para vender bonos de guerra (63a), etc.

Los animales tampoco son ajenos a la situación: perros que son adiestrados en el salvamento de heridos, transporte de municiones, saltos en paracaidas (53b), elefantes que transportan maderas y cañones (59b). No hay que pasar por alto la labor de las mujeres en la guerra, lo que llama la atención a los redactores del NO-DO: mujeres que construyen barcos, aviones, tanques y ¡los manejan! (41a, 50a, 55a).

Los reportajes llegados desde Estados Unidos también hacen referencia a los paises alineados a la causa de los aliados: un desfile en Brasil "dispuestos a ocupar su puesto en ultramar al lado de los aliados" (44a), sus explotaciones de caucho y minerales "tan importantes para la guerra" (55b), la acogida de prisioneros de los campos japoneses (59a); Canadá que participa con su cuota maderera...

En realidad toda una gran nación y sus satélites están preparándose para la gran ofensiva. Si hasta el comienzo de la invasión de Normandía se han tratado en los noticiarios estos temas laterales, a partir de la llegada a Normandía los reportajes sobre el avance en Europa será el centro de atención del NO-DO.

Por supuesto que los alemanes han "terminado las medidas para hacer frente a la invasión" - la cámara muestra fortificaciones de cemento inexpugnables, artillería pesada, alambradas, etc.-, noticia que se da la tercera semana de junio de 1944. En el mismo número de NO-DO paracaidistas norteamericanos se preparan para lanzarse y el texto anuncia "el comienzo de la invasión" (76b).

Todas las imágenes de los siguientes reportajes del noticiario serán de unidades británicas y norteamericanas dispuestas a llegar a Europa. «Ha llegado el dia $\mathrm{D}$ y la hora $\mathrm{H}$ ", rezarán los textos del NO-DO. Barcos y barcazas desembarcando jeeps y artillería mientras la infanteria pone sus pies en las costas francesas al mando de Montgomery e Eisenhower (78b).

Tampoco fue un paseo militar. Los alemanes resisten y se oponen a las vanguardias (80a). Los aliados avanzan hacia Rouen y lanzan proyectiles a Calais, mientras los alemanes bombardean Londres (82a), Avignon, Isigny... es dura la lucha en los distintos centros de población, muchos hombres caen heridos. Siguen llegando tropas a Normandia (83b-85a). 
Se investigan nuevas armas, los alemanes prueban el torpedo humano y los $\mathrm{V}-1$, los norteamericanos, las bombas incendiarias (86a).

Nada es todavía definitivo, aunque a partir del atentado que Hitler sufre en su cuartel general (87b) y aunque las columnas alemanas sigan marchando por Francia, hay en los textos cierto derrotismo que se expresa en frases como «cumplidos los objetivos, las columnas [alemanas] inician la retirada" (87b).

El triunfalismo de la palabra y de la imagen se va volviendo hacia los aliados. 11.000 aviones, 31.000 soldados y $5.000 \mathrm{Tn}$. de explosivos se han acumulado antes de la llegada a Cherburgo. Una instalación de los $\mathrm{V}-1$ ha sido destruída. Caen es ocupado (88a). Alemania ordena la movilización total mientras París es liberado. Guam ha caido en el Pacífico y el $8^{\circ}$ ejército británico está cerca de Florencia. Churchill se entrevista con Roosvelt en el Canadá (94b). Rommel ha muerto (95b) y los aliados llegan a la frontera alemana a la vez que desembarcan en Holanda (96b).

Durante todos estos números del NO-DO, la redacción se va decantando hacia los aliados. Ahora ya hay más informaciones de este lado que de Alemania, diferencia que va pasando del doble al triple o al cuádruple. Al igual que al principio del NO-DO se veían imágenes de la vida alemana, ahora serán de todo lo referente a Estados Unidos y los paises de su órbita.

El transcurrir del conflicto se va viendo a través de los distintos números del noticiario. La "evidente ventaja de los aliados" cambia la cara del NO-DO. El trabajo de los cámaras norteamericanos también es distinto a las noticias enviadas desde Alemania. Predominan los planos más cortos tanto de los asuntos bélicos como los temas referentes a políticos. Se ven los rostros de los que serán los responsables del nuevo orden mundial, mientras que antes existía una mayor distancia de los «héroes» fascistas.

Durante los siguientes treinta números del NO-DO, la guerra seguirá en la cumbre informativa del noticiario, hasta que por fin en el número $124 \mathrm{~b}$ se da la noticia de "Europa en paz", pero ¿a qué precio? Campos de tumbas, zanjas de kilómetros con cadáveres (125a), ciudades destruídas, campos arrasados, millones de refugiados y prisioneros, juicios... y para terminar, Hiroshima y Nagasaki «otra prueba para el enemigo del producto de la guerra” (151b).

Estas palabras podrian servir de cierre para seis años de contienda mundial. El miedo se usará como disuasión para detener futuros posibles enfrentamientos, aunque el nuevo orden mundial y las señales del dolor sufrido serán el freno, sólo por poco tiempo, de próximos conflictos bélicos. 